\title{
An Estimation for Total Digestible Nutrients in Fresh Herbage from a Perennial Ryegrass - White Clover Mixed Pasture
}

\author{
Miwa NAKANO ${ }^{1,2 *}$, Kazuhiro MATOBA ${ }^{1}$ and Yasuko TOGAMURA ${ }^{1}$ \\ ${ }^{1}$ Division of Grassland Farming, Institute of Livestock and Grassland Science, NARO (Nasushiobara, \\ Tochigi 329-2793, Japan)
}

\begin{abstract}
The appropriate nutritional management of grazing dairy cows requires an accurate estimation of the content of total digestible nutrients (TDN) in fresh herbage from grazing pastures. The present study aimed to confirm the accuracy of existing estimations of TDN developed for fresh meadow fescue for perennial ryegrass (PR) - white clover mixed herbage, and to develop a new TDN estimation for PR WC mixed herbage. The herbage was harvested from a PR - WC mixed pasture from April through October. A total of 16 Suffolk wethers were used for this study to evaluate the digestibility of the herbage. The TDN content of the herbage ranged from $68.9 \%$ to $77.7 \%$ dry matter (DM). The TDN estimated using the existing lignin-based model were similar to the actual TDN, whereas the existing organic $\mathrm{b}$ fraction $(\mathrm{Ob})$-based models underestimated the actual TDN. This may have been caused by high $\mathrm{Ob}$ digestibility due to high $\mathrm{Ob}$ content and the same level of lignin content in the herbage, as compared with those of meadow fescue. There were significant negative correlations between TDN content and acid detergent fiber $(\mathrm{P}<0.01)$, lignin $(\mathrm{P}<0.001)$, and $\mathrm{Ob}(\mathrm{P}<0.001)$ contents. These results demonstrated that the TDN content of $\mathrm{PR}-\mathrm{WC}$ mixed herbage could be estimated accurately using the following estimations: TDN $(\% \mathrm{DM})=-4.33$ lignin -0.39 cellulose $+94.64\left(\mathrm{R}^{2}=0.83, \mathrm{P}<\right.$ $0.001)$ or $\mathrm{TDN}(\% \mathrm{DM})=-0.57 \mathrm{Ob}+93.39\left(\mathrm{R}^{2}=0.87, \mathrm{P}<0.001\right)$.
\end{abstract}

Discipline: Animal industry, Grassland

Additional key words: intensive grazing, nutrient characteristics

\section{Introduction}

The utilization of self-supplying feed is an important issue in Japan due to its low self-sufficiency ratio of feed and the higher production costs caused by rising prices of imported feed. Increasing the proportion of dairy cattle grazing on pastures increases the utilization of self-supplying forage (Togamura et al. 2005) and reduces the cost of milk production (Dillon et al. 2008). However, fresh herbage alone is insufficient for maintaining milk production from dairy cows with high genetic potential, even without limitations on quantity and quality (Bargo et al. 2003). In addition, fresh herbage has a high content of rumendegradable protein that causes an imbalance between protein and energy content, resulting in a high loss of nitrogen into the environment (Tamminga 1992, Van Vuuren et al. 1993). Therefore, the grazing of dairy cows with high genetic potential requires appropriate nutritional management to meet the energy needs of the cattle, and to balance the rumen fermentation of nitrogen and carbohydrates. Such appropriate nutritional management requires the accurate estimation of the content of total digestible nutrients (TDN) in fresh herbage from grazing pastures. Although some TDN estimations have been developed for hay and silage (Abe et al. 1985, Deguchi et al. 1997, Weiss et al. 1992), these estimations generally underestimate the TDN of fresh herbage harvested from grazing pastures (Oshita et al. 2007). It is thus necessary to develop a new TDN estimation for fresh herbage.

Oshita et al. (2007) developed TDN estimations for fresh herbage harvested meadow fescue (Festuca elatior L.) (MF) sward used for intensive grazing in cold regions, using fiber content determined by the detergent fiber method (Robertson \& Van Soest 1981, Van Soest et al. 1991) or enzymatic method (Abe et al. 1979). Conversely, perennial ryegrass (Lolium perenne $\mathrm{L}$.) (PR) has been widely used to support the intensive grazing of dairy cattle in the cool regions of Japan, such Hokkaido, Tohoku, and the northern Kanto region. PR in combination with white clover (Trifolium repens L.) (WC) as grass - legume mixed pas-

Present address:

${ }^{2}$ Western Region Agricultural Research Center, NARO (Fukuyama, Hiroshima 721-8514, Japan)

*Corresponding author: e-mail mwnakano@affrc.go.jp

Received 10 May 2017; accepted 25 July 2017. 
ture has been used for its high productivity, palatability, and digestibility (Delagarde et al. 2000). Although the TDN and neutral detergent fiber (NDFom) contents of MF and PR are similar (Sudo 2004), the crude protein (CP) and acid detergent fiber (ADFom) contents are higher in MF than in PR (Sudo 2004, National Agricultural Research Organization 2009). Moreover, legumes (including WC) have different nutritional characteristics (i.e., high $\mathrm{CP}$ and lignin [Lignin(sa)] contents, low NDFom content) than grasses (Ishiguri 1991). These facts suggest that the TDN content of PR - WC mixed herbage may not be accurately estimated by the estimation used for MF. Therefore, the objectives of this study were to confirm the accuracy of the estimations of MF (Oshita et al. 2007) for use with PR WC mixed herbage, and to develop a new TDN estimation for fresh herbage harvested from the PR - WC mixed pasture.

\section{Materials and methods}

\section{Pasture and animals}

The study was conducted in 2008 and 2009 in a PR WC mixed pasture ( $2 \mathrm{ha}$ ) at the Nasu Research Station of the Institute of Livestock and Grassland Science, NARO $\left(36^{\circ} 55^{\prime} \mathrm{N}, 139^{\circ} 55^{\prime} \mathrm{E}\right)$ in the northern Kanto region of Japan. The five-year (2003-2007) average of the mean annual temperature, and the mean monthly temperature in January (the coldest month) and August (the hottest month) were $12.1^{\circ} \mathrm{C}, 0.9^{\circ} \mathrm{C}$, and $23.8^{\circ} \mathrm{C}$, respectively. The pasture had been used for grazing by lactating and non-lactating dairy cattle since 2005, and fertilizer was applied in the amounts of 60 and $30 \mathrm{~kg} \mathrm{~N} \mathrm{ha}^{-1}$ in early April and early June, respectively. Simple renovation and overseeding were conducted during these years. The vegetation contained some unsown species, such as Japanese barnyard millet (Echinochloa esculenta H. Scholz), southern crabgrass (Digitaria ciliaris Koeler), and chickweed (Stellaria media Vill.).

The herbage was harvested without being chopped from part of the pasture ( $0.6 \mathrm{ha}$ ) from May through October 2008 and from April through August 2009 using a model HEGE 212 forage harvester (HEGE Maschinen, Germany). The area had not received fertilizer-N since September 2007 $\left(30 \mathrm{~kg} \mathrm{~N} \mathrm{ha}^{-1}\right.$ ) and was not used for grazing during the study period. This area was divided into 10 plots; each plot would provide sufficient herbage for three days of zero-grazing during the feeding study. Herbage was harvested every two or three days at $10-15 \mathrm{~cm}$ above ground level to simulate defoliation by animals (Wade et al. 1989). The regrowth intervals in each plot were adjusted to 14-25 days. Each plot received $30 \mathrm{~kg} \mathrm{~N} \mathrm{ha}^{-1}$ after cutting in early May and midJune. Harvested herbage was weighted and stored at $4^{\circ} \mathrm{C}$ to preserve its freshness until feeding. Herbage samples used to measure the dry matter (DM) weight were obtained at each harvest, and then weighed and dried at $100^{\circ} \mathrm{C}$ for over $18 \mathrm{~h}$.

A total of 16 Suffolk wethers (i.e., eight wethers in each year, with a mean body weight of $51.6 \pm 8.8 \mathrm{~kg}$ ) were used for this study to evaluate the digestibility of the herbage. Of these wethers, six per study period were kept in individual metabolism pens $(60 \times 120 \mathrm{~cm})$ during the digestion trials. These wethers were supplied with fresh herbage twice daily (at 09:30 and 17:00) in accordance with the maintenance requirements of the Japanese feeding standard for sheep (Agriculture, Forestry and Fisheries Research Council Secretariat 1996). The wethers also had free access to water and a mineral mixture (ZENOAQ Japan). Animal care and experiments were conducted according to the guidelines of the Animal Care Committee of the Institute of Livestock and Grassland Science, NARO, Japan.

\section{Sampling and chemical analysis}

Two to four digestion trials were conducted each month from early May through early October in 2008. In 2009, complementary trials were conducted in April, May, July, and August (1-3 digestion trials per month). The digestion trials in both years began after an adjustment period (8-10 days) to allow the animals to adjust to the fresh herbage. Each sampling period for the herbage and feces consisted of four sampling days, and 3-6 digestion trials per month (total of 26 digestion trials) were conducted over the two years.

Herbage samples in each sampling period were divided into two subsamples. One was stored at $-20^{\circ} \mathrm{C}$ until processing, when the samples were bulked for four sampling days, and the other was separated into PR, which was separated into the "vegetative stage" and "reproductive tillers", WC, other plants, and dead material. The samples were dried at $70^{\circ} \mathrm{C}$ for $48 \mathrm{~h}$, and then the DM weight was measured.

The feces of each wether was collected and weighed during the sampling period to determine the digestibility of the herbage. Part of these fecal samples was dried at $100^{\circ} \mathrm{C}$ for $24 \mathrm{~h}$, and then the DM content was measured. Thirty percent of the daily feces was sampled and stored at $-20^{\circ} \mathrm{C}$. Fecal samples obtained on all four days were mixed. The stored herbage and fecal samples were dried at $60^{\circ} \mathrm{C}$ for 48 $\mathrm{h}$, and then ground in a Wiley mill to pass through a 1-mm screen.

Herbage and fecal samples were analyzed for DM, crude ash (CA), CP, ether extract (EE), and crude fiber (CF) contents according to the methods of the Association of Official Analytical Chemists (1995). The nitrogen-free extract (NFE) content of the herbage was calculated as follows:

$$
\begin{aligned}
\mathrm{NFE}(\% \mathrm{DM})= & 100-(\mathrm{CP}[\% \mathrm{DM}]+\mathrm{EE}[\% \mathrm{DM}]+ \\
& \mathrm{CF}[\% \mathrm{DM}]+\mathrm{CA}[\% \mathrm{DM}])
\end{aligned}
$$




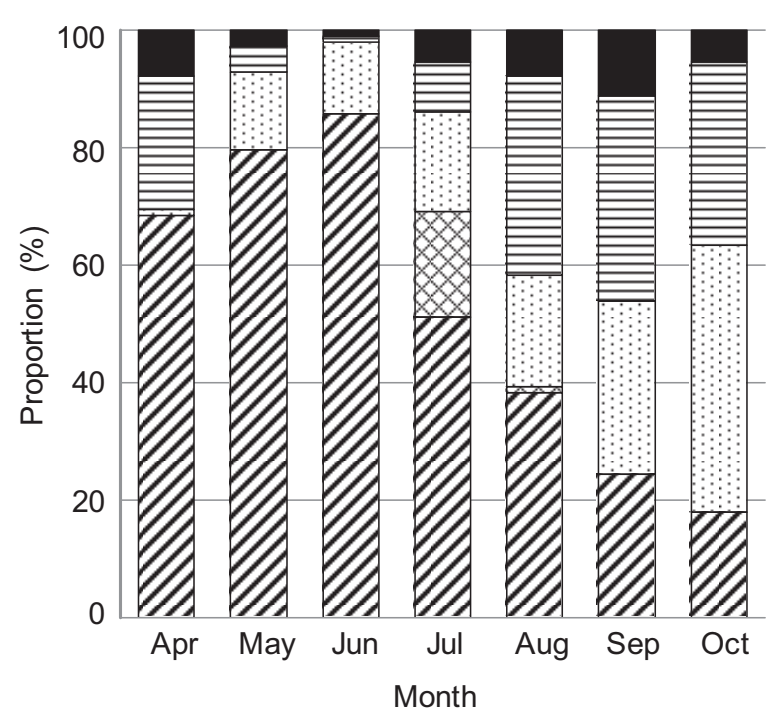

W7 Perennial ryegrass (vegetative stage)

Perennial ryegrass (reproductive tillers)

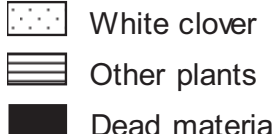

Fig. 1. Seasonal changes in botanical composition of fresh herbage harvested from a perennial ryegrass white clover mixed pasture

NDFom assayed without a heat-stable amylase and expressed exclusive of the residual ash was estimated according to the method of Van Soest et al. (1991). ADFom expressed exclusive of the residual ash and Lignin(sa) determined by the solubilization of cellulose with sulfuric acid was estimated according to the method of Robertson and Van Soest (1981). The organic cell wall (OCW) content that represents both the organic a fraction $(\mathrm{Oa})$ (defined as the high-digestible fraction) and the organic $b$ fraction $(\mathrm{Ob})$ (defined as the low-digestible fraction) was estimated according to the method of Abe et al. (1979).

Nutrient digestibility was calculated using the herbage intake and fecal output of each nutrient from the herbage. The TDN content of herbage was calculated as follows:

$\mathrm{TDN}(\% \mathrm{DM})=$ digestible $\mathrm{CP}(\% \mathrm{DM})+$ digestible CF (\% DM) + digestible NFE (\% DM) + $2.25 \times$ digestible $\mathrm{EE}(\% \mathrm{DM})$

\section{Statistical analysis}

All analyses were conducted using SAS (version 9.2; SAS Institute, 2004). Based on our monitoring period, data was available for May, July, and August in both years. Therefore, we analyzed the data from these months using two-way ANOVA with the effects of year, month, and their interaction. Because we observed no significant year effect, we pooled the data where all data for these three months represent the average values for each month in both years. The nutrient digestibility and TDN data were analyzed using the GLM procedure. When a significant month effect was observed, the effects of the month were compared using polynomial contrasts (linear and quadratic). Pearson's correlation coefficients of TDN with the nutritional contents and digestibility of herbage were determined using the CORR procedure. TDN estimations based on some nutritional contents were calculated using the REG procedure.

\section{Results and discussion}

Figure 1 shows the seasonal changes in the botanical composition of fresh herbage. On a dry-weight basis, the relative proportion of $\mathrm{PR}$ (at the vegetative stage) in the fresh herbage was approximately $70 \%$ to $85 \%$ from April to June, and decreased from July (51\%) to October (18\%). Simultaneously, the relative proportion of WC increased from April (2\%) to October (45\%). The relative proportion of PR (reproductive tillers) was high in July (17\%), whereas those of the other grasses and forbs were high in April and after August (approximately 20-35\%). The summer air temperature in the northern Kanto region is higher than that in the northern Tohoku region and Hokkaido, and this difference may adversely affect the growth of PR.

Tables 1 and 2 show the chemical composition and nutrient digestibility, including the TDN content of herbage obtained from the PR - WC mixed pasture, respectively. The CP content increased from April (18.9\% DM) to October (25.5\% DM) (Table 1). Conversely, CP digestibility changed slightly but significantly during the study period ( $\mathrm{P}$ $<0.05$, Table 2). The CF, NDFom, ADFom, Lignin(sa), and Ob contents were numerically highest in July $(26.7 \%, 50.4 \%$, $30.5 \%, 3.4 \%$, and 40.5\% DM, respectively; Table 1). Lignin(sa) and $\mathrm{Ob}$ contents remained high after July (Table 1). NDFom digestibility was highest in May (83.9\%) and decreased during the summer and autumn (69.9-73.7\%) linearly $(\mathrm{P}<0.001)$ and quadratically $(\mathrm{P}<0.001)$ (Table 2). After August, the herbage included a high proportion of WC and a small amount of dead material, with a small proportion of PR (reproductive tillers) (Fig. 1). WC has low NDFom content and high ratios of ADFom and Lignin(sa) within NDFom (Ishiguri 1991, National Agricultural Research Organization 2001). The maturation of herbage generally increases the indigestible fiber, including ADFom and Lignin(sa), due to increased lignification and a decreased ratio of leaves to stems (Delagarde et al. 2000), which result in decreased digestibility (Brink \& Fairbrother 1994). Therefore, the low NDFom digestibility after August may have been caused by decreasing NDFom content and increasing ADFom and Lignin(sa) content due to increasing proportions of WC, other plants such as mature grasses, and 
Table 1. The chemical composition of the herbage harvested from perennial ryegrass - white clover mixed pasture

\begin{tabular}{lrrrrrrr}
\hline \hline & Apr & May & Jun & Jul & Aug & Sep & Oct \\
\hline DM (\%) & 17.8 & 17.0 & 15.9 & 16.6 & 16.1 & 20.0 & 15.8 \\
CA (\% DM) & 10.3 & 11.2 & 10.9 & 11.7 & 11.0 & 9.7 & 10.3 \\
CP (\% DM) & 18.9 & 20.2 & 18.7 & 19.8 & 24.4 & 23.6 & 25.5 \\
EE (\% DM) & 5.5 & 4.4 & 4.3 & 4.5 & 4.5 & 4.4 & 4.3 \\
CF (\% DM) & 21.0 & 22.3 & 26.1 & 26.7 & 21.2 & 19.8 & 18.8 \\
NFE (\% DM) & 44.3 & 41.8 & 40.0 & 37.4 & 38.9 & 42.4 & 41.1 \\
NDFom (\% DM) & 42.5 & 44.7 & 48.2 & 50.4 & 43.6 & 39.4 & 36.1 \\
ADFom (\% DM) & 23.4 & 24.8 & 28.8 & 30.5 & 25.2 & 23.8 & 23.1 \\
Lignin(sa) (\% DM) & 2.4 & 1.7 & 2.6 & 3.4 & 3.0 & 3.2 & 3.3 \\
OCW (\% DM) & 45.1 & 45.8 & 50.7 & 52.8 & 46.8 & 44.1 & 41.9 \\
Oa (\% DM) & 17.7 & 19.0 & 16.5 & 12.3 & 8.1 & 5.8 & 5.1 \\
Ob (\% DM) & 27.4 & 26.8 & 34.2 & 40.5 & 38.7 & 38.3 & 36.8 \\
\hline
\end{tabular}

DM, dry matter; CA, crude ash; CP, crude protein; EE, ether extract; CF, crude fiber; NFE, nitrogen-free extract; NDFom, neutral detergent fiber not assayed with a heat-stable amylase expressed exclusive of residual ash; ADFom, acid detergent fiber expressed exclusive of residual ash; Lignin(sa), lignin determined by solubilization of cellulose with sulfuric acid; OCW, organic cell wall; Oa, organic a fraction in cell wall; Ob, organic b fraction in cell wall.

Values were averages of some samples conducted in each month in 2007 and 2008; April, n= 3; May, n=6; June, n = 3; July, $\mathrm{n}=5$; August, $\mathrm{n}=3$, September, $\mathrm{n}=3$, October, $\mathrm{n}=3$.

Table 2. Seasonal change in nutrient digestibility and total digestible nutrients (TDN) of herbage harvested from perennial ryegrass - white clover mixed pasture

\begin{tabular}{lcccccccccccc}
\hline \hline & Apr & May & Jun & Jul & Aug & Sep & Oct & SEM & \multicolumn{3}{c}{ P value } \\
\cline { 6 - 11 } & & & & & & & & & & Month & L & Q \\
\hline Digestibility (\%) & & & & & & & & & & & & \\
DM & 79.6 & 81.6 & 78.3 & 73.4 & 74.9 & 75.8 & 76.9 & 0.65 & $* * *$ & $* *$ & $* * *$ \\
CP & 78.7 & 82.4 & 81.3 & 79.1 & 80.4 & 81.6 & 82.9 & 0.42 & $*$ & NS & NS \\
NDFom & 81.7 & 83.9 & 78.6 & 73.7 & 74.2 & 69.9 & 72.2 & 1.12 & $* * *$ & $* * *$ & $* * *$ \\
EE & 61.9 & 55.7 & 59.3 & 48.5 & 45.5 & 52.4 & 53.6 & 1.36 & $*$ & $*$ & $* *$ \\
NFE & 85.3 & 87.6 & 81.8 & 76.7 & 80.2 & 80.8 & 82.3 & 0.83 & $* * *$ & $* * *$ & $* * *$ \\
TDN (\%DM) & 77.6 & 77.7 & 74.5 & 68.9 & 70.9 & 72.7 & 73.3 & 0.71 & $* * *$ & $* *$ & $* * *$ \\
\hline
\end{tabular}

$* \mathrm{P}<0.05 ; * * \mathrm{P}<0.01 ; * * * \mathrm{P}<0.001 ; \mathrm{L}$, linear; $\mathrm{Q}$, quadratic; NS, not significant.

$\mathrm{DM}$, dry matter; CP, crude protein; NDFom, neutral detergent fiber not assayed with a heat stable amylase expressed exclusive of residual ash; EE, ether extract; NFE, nitrogen free extract; TDN, total digestible nutrients.

dead material.

The TDN content of the herbage (Table 2) was $77.6 \%$ and $77.7 \%$ DM in April and May, respectively. It decreased from May to July (to $68.9 \% \mathrm{DM}$ ), then increased again until October $(73.3 \% \mathrm{DM})$ quadratically $(\mathrm{P}<0.001)$. This seasonal variation paralleled that of DM digestibility, which decreased from May to July, then increased. Ishiguri (1991) reported that it was difficult to obtain herbage containing high TDN content in the summer due to the potential for low soluble carbohydrates, high indigestible content, and low digestibility if the regrowth intervals between harvests were reduced. Therefore, in the present study, the low potential quality of the herbage and PR (reproductive tillers) reflected the decline of TDN content during the summer, particularly in July.
Figure 2 shows the relation between the actual TDN content and estimated TDN content using the models for MF (Oshita et al. 2007). The estimated TDN using the Lignin(sa) model $(\mathrm{TDN}=-6.1$ Lignin[sa] +87.3$)$ was similar to the actual TDN (Y $=0.97 \mathrm{X}-0.58$, Fig. 2 [a]), although a lower $\mathrm{R}^{2}$ was detected than that in the other models $\left(\mathrm{R}^{2}=0.72\right)$. The $\mathrm{Ob}(\mathrm{TDN}=-0.7 \mathrm{Ob}+92.3)$ and $\mathrm{OCC}+\mathrm{Oa}(\mathrm{TDN}=0.7[\mathrm{OCC}+\mathrm{Oa}]+26.3)$ models underestimated the actual TDN despite significant positive correlations $\left(\mathrm{Y}=1.06 \mathrm{X}-9.58, \mathrm{R}^{2}=0.87\right.$, Fig. $2[\mathrm{~b}]$ and $\mathrm{Y}=$ $1.09 X-15.74, R^{2}=0.90$, Fig. 2 [c], respectively). The ranges of actual TDN in the herbage $(66 \%$ to $79 \% \mathrm{DM})$ and Lignin(sa) content $(1.5 \%$ to $3.6 \% \mathrm{DM})$ in this study were similar to the ranges reported by Oshita et al. (2007). In contrast, the range of $\mathrm{Ob}$ content in herbage in this study was 

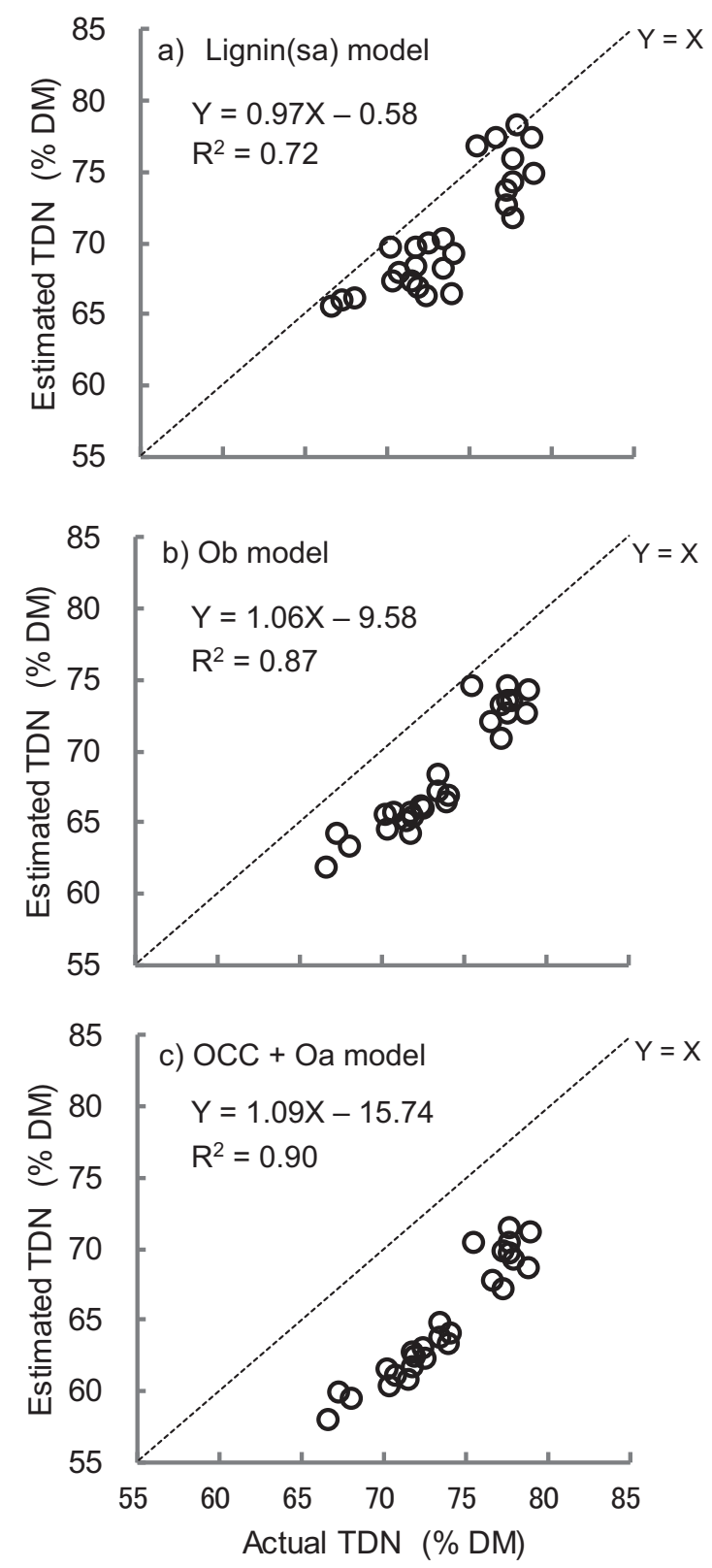

Fig. 2. Relation between actual TDN and estimated TDN calculated using a) lignin (Lignin[sa]) model (TDN = -6.1 Lignin[sa] +87.3$)$, b) organic b fraction (Ob) model $($ TDN $=-0.7 \mathrm{Ob}+92.3)$, and c) organic cellular contents $(\mathrm{OCC})+$ organic a fraction (Oa) model $(T D N=0.7[O C C+$ Oa] +26.3$)($ Oshita et al. 2007)

higher than that reported by Oshita et al. (2007) (25.4-43.5\% DM vs $16.7-33.5 \%$ DM, respectively). These facts indicated that the ratio of Lignin(sa) within $\mathrm{Ob}$ in the present study was lower than that in the study by Oshita et al. (2007), which would cause the high $\mathrm{Ob}$ digestibility of herbage in this study in comparison to that in the study by Oshita et al. (2007), because $\mathrm{Ob}$ digestibility could be explained by the lignin content (Abe et al. 1985). This high Ob digestibility caused underestimation of the actual TDN using the $\mathrm{Ob}$ and
Table 3. The correlation coefficients of TDN with the contents and digestibility of the nutrient fractions of herbage

\begin{tabular}{lcc}
\hline \hline \multicolumn{1}{c}{ Item } & Content & Digestibility \\
\hline $\mathrm{CP}$ & -0.14 & $0.42^{*}$ \\
$\mathrm{EE}$ & 0.38 & $0.67^{*}$ \\
NDFom & -0.33 & $0.77^{* * *}$ \\
ADFom & $-0.60^{* *}$ & \\
Lignin(sa) & $-0.85^{* * *}$ & \\
OCW & $-0.49^{*}$ & \\
Oa & $0.60^{* *}$ & \\
Ob & $-0.93^{* * *}$ & \\
\hline
\end{tabular}

$* \mathrm{P}<0.05 ; * * \mathrm{P}<0.01 ; * * * \mathrm{P}<0.001$.

$\mathrm{CP}$, crude protein; EE, ether extract; NDFom, neutral detergent fiber not assayed with a heat-stable amylase expressed exclusive of residual ash; ADFom, acid detergent fiber expressed exclusive of residual ash; Lignin(sa), lignin determined by solubilization of cellulose with sulfuric acid; OCW, organic cell wall; Oa, organic a fraction in cell wall; $\mathrm{Ob}$, organic $\mathrm{b}$ fraction in cell wall.

OCC + Oa models. Ob content in the herbage of this study increased from June when there were relatively small proportions of mature grasses, other plants, and dead material. Therefore, the high $\mathrm{Ob}$ content from summer would be caused not only by an increase in the relative proportions of other plants and dead material, but also by the characteristics of the herbage (including PR and WC) in grazing pastures in the northern Kanto region due to higher temperatures than those in Hokkaido.

Table 3 shows the correlation coefficients of TDN content with the contents and digestibility of the nutrient fractions of herbage. There were significant negative correlations between the TDN content and the ADFom ( $\mathrm{P}<$ $0.01)$, Lignin(sa) $(\mathrm{P}<0.001)$, OCW $(\mathrm{P}<0.05)$, and $\mathrm{Ob}(\mathrm{P}<$ 0.001 ) contents, respectively. Generally, fiber, especially NDFom, ADFom, and Lignin(sa), was the most common variable used to predict the energy content of feeds owing to high correlations (Abe et al. 1985, Conrad et al. 1984). The correlation between TDN and NDFom was low $(-0.33, \mathrm{P}>$ 0.05 ) in this study. The NDFom content of the herbage collected in autumn (September and October) was lower than that in the other seasons (Table 1), whereas the TDN content in autumn herbage was similar to that of the other seasons (Table 2). The proportion of WC and other plants, including forbs, was high in autumn herbage (Fig. 1). The large change in the proportions within herbage, especially the proportion of WC that had different characteristics of fiber (low NDFom and high Lignin(sa) contents) compared with grass, might affect the low correlation of TDN with NDFom. Conversely, a positive high correlation coefficient of TDN content with NDFom digestibility was also detected $(\mathrm{P}<$ 
Table 4. TDN estimations for fresh herbage harvested from perennial ryegrass - white clover mixed pasture

\begin{tabular}{llcc}
\hline \hline \multicolumn{1}{c}{ Item } & \multicolumn{1}{c}{ Estimation } & $\mathrm{R}^{2}$ & P value \\
\hline Lignin(sa) & -4.57 Lignin(sa) +86.20 & 0.72 & $<0.001$ \\
Lignin(sa), cellulose & -4.33 Lignin(sa) -0.39 cellulose +94.64 & 0.83 & $<0.001$ \\
Ob & $-0.57 \mathrm{Ob}+93.39$ & 0.87 & $<0.001$ \\
\hline
\end{tabular}

Lignin(sa), lignin determined by solubilization of cellulose with sulfuric acid; cellulose, calculated as ADFom minus Lignin(sa); Ob, organic $b$ fraction in cell wall.

Lignin(sa), cellulose and $\mathrm{Ob}$ are expressed as \% DM.

0.001), which suggested that the availability of fiber should be considered for the estimation of TDN content. The Lignin(sa) and $\mathrm{Ob}$ contents, with which high correlation coefficients with TDN were detected in this study, could explain the availability of fiber. Lignin(sa) limits the digestion of the structural polysaccharides, cellulose, and hemicellulose (Hatfield et al. 1999), and controls the amount of fiber that can be digested (Jung \& Allen 1995). Therefore, Lignin(sa) plays an important role relative to the digestible energy value of the forage (Jung \& Allen 1995). The Ob measured as residual organic matter of OCW digested by cellulose hydrolysis is defined as a low-digestible fraction of fiber (Abe et al. 1979). Therefore, it would be appropriate to use the components with high correlation coefficients with TDN in predicting the TDN content of herbage.

Table 4 shows the TDN estimations for fresh herbage from the PR - WC mixed pasture. The actual TDN exhibited linear relations with the Lignin(sa) and $\mathrm{Ob}$ contents, respectively, as follows:

$$
\begin{aligned}
& \mathrm{TDN}=-4.57 \operatorname{Lignin}(\mathrm{sa})+ \\
& 86.20\left(\mathrm{R}^{2}=0.72, \mathrm{P}<0.001\right) \\
& \mathrm{TDN}=-0.57 \mathrm{Ob}+93.39\left(\mathrm{R}^{2}=0.87, \mathrm{P}<0.001\right)
\end{aligned}
$$

where TDN, Lignin(sa), and $\mathrm{Ob}$ are expressed as \% DM. Although the Lignin(sa)-based equation was similar to that for MF (TDN =-6.1 Lignin(sa) + 87.3, Oshita et al. 2007), the coefficient of determination of the Lignin(sa)-based equation was slightly lower than that of the Ob-based one. Multicomponent models can be alleviated of the coefficient of determination because ADFom, when a relatively high coefficient of correlation with TDN is detected, is divided into two fractions-cellulose and Lignin(sa). The multicomponent model was calculated based on these two contents as follows:

$$
\begin{aligned}
& \text { TDN }=-4.33 \text { Lignin }(\mathrm{sa})-0.39 \text { cellulose }+ \\
& 94.64\left(\mathrm{R}^{2}=0.83, \mathrm{P}<0.001\right)
\end{aligned}
$$

where TDN, Lignin(sa), and cellulose were expressed as \% DM. Cellulose content was calculated as ADFom minus
Lignin(sa). A high coefficient of determination was detected in this equation. Therefore, a Lignin(sa)-based estimation would be improved by adding cellulose (a low digestible fiber) as a variable. The Ob-based estimation has a high coefficient of determination and was reported to be effective for introducing information on fiber digestibility to improve the accuracy of estimating TDN for hay (Abe et al. 1985). Therefore, Ob defined as a low-digestible fraction of fiber would be a suitable indicator of TDN estimation. Although the approximate TDN values of PR - WC mixed herbage could be estimated using a Lignin(sa)-based model for MF, the Ob-based estimation should be used when the fiber fraction is analyzed using an enzymatic method (Abe et al. 1979), and the Lignin(sa) and cellulose-based estimations should be used when using detergent fiber methods (Robertson \& Van Soest 1981, Van Soest et al. 1991) to estimate the TDN content of PR - WC mixed herbage when detailed TDN values are needed.

Although the present study suggested effective TDN estimations for herbage collected from a PR - WC mixed pasture, a potential limitation should be considered. The average plant length reached $40.7 \pm 12.0 \mathrm{~cm}$ (mean $\pm \mathrm{SD}$ ) due to rapid growth in early summer and elongation of the stems after the summer, although the harvesting interval corresponded to the general grazing interval in intensive grazing rotation systems in this region. In a pasture, grazing cattle would feed on successive layers from the top down (Wade et al. 1989) and select leaves containing high nutritional quality as compared with stems (Hodgson et al. 1994). Therefore, we set the cutting height at $10-15 \mathrm{~cm}$ above ground level so that our harvest mostly included the leaves that grazing cattle would preferentially ingest. Although the CP and NDFom contents in the present study were similar to those of grazing grass under the intensive grazing of dairy cattle (Togamura et al. 2005), the cutting height of herbage in this study should be taken into consideration.

In conclusion, the TDN content of fresh herbage harvested from the PR - WC mixed pasture in the northern Kanto region was somewhat underestimated using the estimations for MF (Oshita et al. 2007); this could be caused by high $\mathrm{Ob}$ digestibility due to the high $\mathrm{Ob}$ content and low 
Lignin(sa) concentration in $\mathrm{Ob}$ of the herbage, as compared with those in MF. The TDN content in this study was highly correlated with the $\mathrm{Ob}$ and Lignin(sa) contents, and could be estimated using new Ob or Lignin(sa) and cellulose contentbased estimations. These estimations would help determine appropriate nutritional management for the intensive grazing of dairy cattle on the PR - WC mixed pasture. In addition, although underestimation of the TDN content of PR - WC mixed fresh herbage was detected using the estimations for MF, the difference between actual and estimated values was small, particularly when using the Lignin(sa)-based estimation, which suggested that the estimations for fresh herbage could be unified. In the future, it will be necessary to develop some common estimations for fresh herbage on grazing pastures.

\section{Acknowledgement}

The authors wish to thank Dr. H. Ishizaki, Dr. M. Fukasawa, and Dr. S. Haga for their useful suggestions, and Mr. H. Muroi and Ms. A. Sueta for their technical assistance. The authors would also like to acknowledge the valuable assistance in animal and field management provided by members of the animal and crop management section of the Institute of Livestock and Grassland Science, NARO.

\section{References}

Abe, A. et al. (1979) Application of enzymatic analysis with glucoamylase, pronase and cellulose to various feeds for cattle. J. Anim. Sci., 48, 1483-1490.

Abe, A. et al. (1985) Assessment of total digestible nutrients (TDN) of hays from its chemical composition. Nicchiku Kaihou (Jpn. J. Zootech. Sci.), 56, 12-19 [In Japanese with English summary].

Agriculture, Forestry and Fisheries Research Council Secretariat (1996) Nihon Shiyo Hyojun Menyo (Japanese feeding standard for sheep). The Ministry of Agriculture, Forestry and Fisheries, Japan Livestock Industry Association, Tokyo, Japan [In Japanese].

Association of Official Analytical Chemists (1995) Official Methods of Analysis of the Association of Official Analytical Chemists, 16th ed. Association of Official Analytical Chemists, Virginia, USA.

Bargo, F. et al. (2003) Production and digestion of supplemented dairy cows on pasture. J. Dairy Sci., 86, 1-42.

Brink, G. E. \& Fairbrother, T. E. (1994) Cell wall composition of diverse clovers during primary spring growth. Crop Sci., 34, 1666-1671.

Conrad, H. R. et al. (1984) Estimating net energy lactation from components of cell solubles and cell walls. J. Dairy Sci., 67, 427-436.

Deguchi, K. et al. (1997) Estimating of total digestible nutrients of temperate grasses and differences of estimation accuracy among species. Nihon Souchi Gakkaishi (Jpn. J. Grassl. Sci.), 43 (Supplement), 290-291 [In Japanese].

Delagarde, R. et al. (2000) Vertical distribution of biomass, chemical composition and pepsin-cellulase digestibility in a perennial ryegrass sward: interaction with month of year, regrowth age and time of day. Anim. Feed Sci. Technol., 84, 49-68.

Dillon, P. A. et al. (2008) Future outlook for the Irish dairy industry: a study of international competitiveness, influence of international trade reform and requirement for change. Int. J. Dairy Technol., 61, 16-29.

Hatfield, R. D. et al. (1999) Cell wall structural foundations: molecular basis for improving forage digestibilities. Crop Sci., 39, 27-37.

Hodgson, J. et al. (1994) Foraging behavior in grazing animals and its impact on plant communities. In Forage Quality, Evaluation, and Utilization (ed. Fahey, G. C.). Lincoln, USA, 796-827.

Ishiguri, T. (1991) Changes in digestibility and voluntary intake of forages with growth progress. Hokkaidoritsu Nougyoshikenjo Hokoku (Rep. Hokkaido Prefect. Agric. Exp. Stn.), 75, 1-86 [In Japanese with English summary].

Jung, H. G. \& Allen, M. S. (1995) Characteristics of plant cell walls affecting intake and digestibility of forages by ruminants. J. Anim. Sci., 73, 2774-2790.

National Agricultural Research Organization (2009) Nihon Hyojun Shiryo Seibunhyo (Standard Tables of Feed Composition in Japan). Japan Livestock Industry Association, Tokyo, Japan [In Japanese].

Oshita, T. et al. (2007) The estimation for total digestible nutrient (TDN) of the fresh grass harvested Medfescue sward. Atarashii Kenkyu Seika, 64-66 [In Japanese].

Robertson, J. B. \& Van Soest, P. J. (1981) The detergent system of analysis. In The Analysis of Dietary Fibre in Food (eds. James, W. P. T. and Theander, O.), Marcel Dekker, New York, 123-158.

Sudo, K. (2004) Establishment of an intensive grazing system for lactating cows - Focusing on meadow fescue pasture-. Hokkaido Nokenho (Res. Bull. Natl. Agric. Res. Cent. for Hokkaido Reg.), 181, 43-87 [In Japanese with English summary].

Tamminga, S. (1992) Nutrition management of dairy cows as a contribution to pollution control. J. Dairy Sci., 75, 345-357.

Togamura, Y. et al. (2005) Nutritive value of intensive grazed pasture. Eiyo Seiri Kenkyukaiho (Proceedings of Japanese Society for Animal Nutrition and Metabolism), 49, 49-57 [In Japanese].

Van Soest, P. J. et al. (1991) Methods for dietary fiber, neutral detergent fiber, and nonstarch polysaccharides in relation to animal nutrition. J. Dairy Sci., 74, 3583-3597.

Van Vuuren, A. M. et al. (1993) Effects of partial replacement of ryegrass by low protein feeds on rumen fermentation and nitrogen loss by dairy cows. J. Dairy Sci., 76, 2982-2993.

Wade, M. H. et al. (1989) The dynamics of daily area and depth of grazing and herbage intake of cows in a five-day paddock system. Proceedings of the $16^{\text {th }}$ International Grassland Congress, Nice, France, 1111-1112.

Weiss, W. P. et al. (1992) A theoretically-based model for predicting total digestible nutrient values of forages and concentrates. Anim. Feed Sci. Technol., 39, 95-110. 